\title{
Article
}

\section{Dwelling in-between}

Giddens, Sara, Judge, Tony and Law, John

Available at http://clok.uclan.ac.uk/32804/

Giddens, Sara ORCID: 0000-0003-0680-2189, Judge, Tony and Law, John (2019) Dwelling in-between. Choreographic Practices, 10 (2). pp. 213-237. ISSN 2040-5669

It is advisable to refer to the publisher's version if you intend to cite from the work. http://dx.doi.org/10.1386/chor_00004_1

For more information about UCLan's research in this area go to http://www.uclan.ac.uk/researchgroups/ and search for < name of research Group>.

For information about Research generally at UCLan please go to http://www.uclan.ac.uk/research/

All outputs in CLoK are protected by Intellectual Property Rights law, including Copyright law. Copyright, IPR and Moral Rights for the works on this site are retained by the individual authors and/or other copyright owners. Terms and conditions for use of this material are defined in the policies page.

\section{CLoK}

Central Lancashire online Knowledge www.clok.uclan.ac.uk

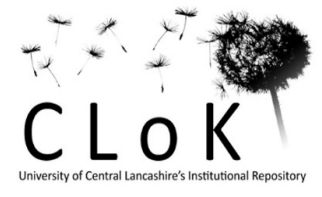




\section{SARA GIDDENS}

University of Central Lancashire

\section{TONY JUDGE}

Leeds Arts and Edge Hill Universities

JOHN LAW

University of Central Lancashire

\section{Dwelling in-between}

\section{Keywords}

audiences

Bodies in Flight

choreography

dwelling

site-specific

still-ing

\section{Abstract}

Choreographer Sara Giddens reflects upon how making a series of ambulant performance works, The Dream-Walks, invited her to dwell in space-times in-between, and how a resulting stepping aside heralded the opening up of a fundamental change in her relationship to audiences. Drawing upon a range of philosophers, including Bachelard, Heidegger and Rancière, Giddens reflects upon the impact that dwelling in those in-between space-times has had on her professional and pedagogic practice.

16 short video clips, taken from the Eight Dream-Walks can be viewed at (https://www.bodiesinflight.co.uk/events/dwelling-in-between-choreographic-practices-102/).

\section{Dwelling with stillness}

As a choreographer, I had been using the verb (to) dwell in the studio for several years to suggest a staying with, a not moving on or away from material, however irksome, in both a temporal and 
spatial sense. In part, its usage was influenced by my yin-yoga practice. The practice of yin-yoga is concerned with releasing fascia, the connective tissue around muscles, to make sitting still for meditation more comfortable. With this practice one is invited to stay with, to dwell in each posture and to let gravity do the work and allow the fascia to relax and stretch. In other words, one must let go to progress.

I am also influenced profoundly by my collaboration with writer and academic prof. Simon Jones (University of Bristol, UK). We co-direct Bodies in Flight, making performance that at its heart aims to move audiences emotionally and spiritually. For thirty-years, through many, many collaborations with a range of sonic, visual and performance artists, we have insisted on the mix of ideas and materials, words and images, voices and bodies, upon philosophy and poetry, and developing site specific, theatre and gallery works that challenge and re-energize the conventional relationship between audiences and performers, and audiences and place. Such a long-term collaboration has allowed us to have the time and courage to persist with ideas and complementary aesthetic and material interests, to dwell alone and together, often picking up with one show where the last left off.

Theologist Holger Zaborowski's article 'Towards a phenomenology of dwelling' helps in framing the delicacy of dwelling. Zaborowski observes that'no one truly dwells who lives as if he could move again at any moment. At the same time no one truly dwells who lives as if he were going to dwell forever and ever exactly where he is' (2005: 492). Dwelling has been and continues to be a delicate balance. A somewhat slippery customer, a staying-with whilst recognizing that change will inevitably take place. Nevertheless, dwelling had become a central part of my personal and professional practice, part of an attitude to self and others and those other things and spaces around me, part of my methodology.

However, it was through the Dream-Walks, a series of ambulant performance walks made between 2009 and 2016 across Singapore and a range of UK towns and cities, that I became increasingly committed to creating space-times in which makers and audiences could dwell together. The Dream-Walks heralded a move towards considering audiences in a much more deliberate and active way. Moreover, for me, creating such dwelling space-times became inexorably coupled with a slowing down, a stepping aside and perhaps inevitably, for one who has a tendency to head towards extremities, such a slowing led to a fascination with stillness, or to be more accurate that which I have come to define as still-ing. I wondered how might still-ing invigorate or re-invigorate a makers' relationship to audiences?

For me, still-ing like performance making is active; it is full of intention and ownership, it is becoming. This attention to still-ing, this slowing to notice and attend to, became part of, as French philosopher Gaston Bachelard expresses in, The Poetics of Space, my growing'slower ontology' ([1958] 1994: 215). It was not necessarily, as Andre Lepecki poetically notes in Exhausting Dance (2006: 1), inextricably bound up in exhaustion, or as writer and musician Michal Sapir reiterates, always content dwelling had

become a

central part of

my personal

and professional

practice, part of

an attitude to self

and others and

those other things

and spaces around

me, part of my

methodology

I wondered how

might still-ing

invigorate or re-

invigorate a makers

relationship to

audiences? 


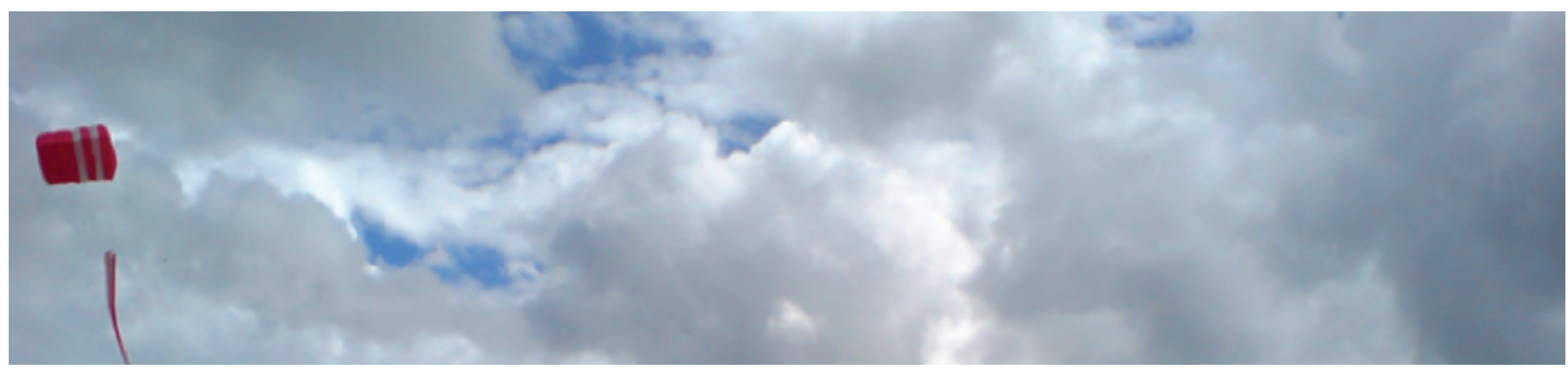

Figure 1: Dream-Walk, Skegness Beach, 2013. Photographer: Tony Judge. (See video one, Skegness Beach). 
with 'occupying a discomfort zone' (2006: 50), although it could be both. Creating space-times to dwell, to attend to still-ing, required an opening up and an openness to that I could not have ever fully predicted. Such openings have inevitably brought my attention to things, persons and places that I would not normally have noticed or at times would have liked to avoid. Not least, such attention manifested a mirror upon myself, and this has been and continues to be revealing, and at times uncomfortable. Even a terse pre-amble into this delicate territory demanded such care and attention.

In his essay 'Building dwelling thinking' ([1951] 1978), Martin Heidegger argues that to build a space, any kind of space, 'properly' and with due care and attention, we should come to this by way of dwelling. He states that the meaning of the word dwelling has come to be mis-used, citing the association between dwelling as a space for a home, and suggests the one is not synonymous with the other. Just because a house may provide a roof over our heads, this does not mean that we dwell in it. Conversely a place where we feel'at home' (Heidegger [1951] 1978: 347) does not mean we stay there. He elucidates this by way of a carefully crafted, etymological journey through Old English, High German, Old Saxon and Gothic, arguing that dwelling is already in relation to another, a neardweller through the German word'Nachgebauer' (in English neighbour) (Heidegger [1951] 1978: 349), and that 'proper' dwelling carries with it a necessity to value and care for those beings and things within our'domain' (Heidegger [1951] 1978: 347).

As a human-being and like so many performance-makers, I am inherently interested in building spaces and relationships, in enabling and creating invitations. Heidegger argues that we need to think of building as intimately connected to dwelling, and that both building and dwelling are fundamental to and in constant relationship to thinking. Heidegger's deliberate absence of punctuation between the three words, 'Building dwelling thinking', suggests an emphasis on their equality and symbiosis. Heidegger pursues the relationship between thinking ${ }^{1}$ and building through dwelling, bemoaning how too often they are separated. He draws particular attention to the importance of the one listening to the other, a theme that had and would become increasingly prevalent in my on-going process and practice. Elucidating upon this interrelationship, Heidegger writes '[b]uilding and thinking are, each in its own way, inescapable for dwelling. The two, however, are also insufficient for dwelling so long as each busies itself with its own affairs in separation, instead of listening to each other' ([1951] 1978: 362). Practiced collaborators and facilitators will find such sentiments familiar.

I longed to create dwelling places that would put still-ing centre-stage and I was still tustling with the stubborn, slippery inter-connectedness of dwelling and still-ing. A persistent question kept re-emerging through the practice 'can there be a still-ing without a Dwelling?' I began to consider how I might employ still-ing as a means of engaging performers and audiences within a live, faceto-face encounter, so that they may be able to dwell alone still together. How might such spacetimes be created?
Creating space-

times to dwell,

to attend to still-

ing, required an

opening up and

an openness to

that I could not

have ever fully

predicted. 


\section{'that mortals ever}

search anew for

the essence of

dwelling, that

they must ever

learn to dwell
Heidegger suggests that dwelling should be intimately connected with that which he names the 'fourfold' ([1951] 1978: 352). This 'fourfold' is made up of the earth, sky, mortals and divinities, and critically, it is in this 'fourfold' that space meets time through the sky and earth and in relation to its sun and moon and the passing of the seasons. Through the 'fourfold' Heidegger demonstrates how space and time are both separate and inseparable. Each part of this 'fourfold' has its own 'oneness' (Heidegger [1951] 1978: 351), and yet is utterly inter-connected. Significantly for Heidegger, my developing practice, and extremely pertinent to our current political and environmental climate, the 'real plight' for us as humans is that we have lost our ability to dwell, to exist in relation to the fourfold, 'that mortals ever search anew for the essence of dwelling, that they must ever learn to dwell' (Heidegger [1951] 1978: 363, original emphasis).

Writing in this linear way suggests that my reading perhaps led me to dwelling; this is not the case. As I have outlined in the opening paragraph such attention to dwelling emerged from my daily yin-yoga practice and out of the process of making over many, many years. However, finding and absorbing 'Building dwelling thinking' provided a lens, maybe even a microscope, through which to view and review the Dream-Walks. Reading Heidegger certainly helped me to become able to articulate this, that is, to be able to articulate a particular way of approaching and understanding this performance research.

The Dream-Walks (2009-2016) were commissioned by The Singapore Arts Foundation, Dance4, Bristol's Mayfest and Wirksworth Arts Festivals, as part of the Big Dance for the SO festival in Skegness, Connected Communities for Cardiff, and for Know Your Bristol. Originally conceived to take place in the early morning commute, The Dream-Works, performed in Singapore, Nottingham and Bristol (2009-10) (see video two, stepping-aside), asked audiences to follow the performers through the city streets, occasionally stepping aside and resting in places in-between the flow of the everyday. The audiences listened, through individual earphones, to a pre-recorded and live soundtrack, made up of text, original composed music and ambient sounds taken from the surrounding environments. Initial research enabled us to find a rhythm for the walks - the technology (a transmitter and receiver) demanded that the performers (wearing microphones) had to keep within a particular range, both of each other and their audiences. This technical demand became a guiding principle for the structuring of the walks. The distinction between following the performers through the city streets, and stepping aside, passing by the here and now to the just there then, to pausing together in the in-between, evoked different tones. We never re-traced our steps. There was always a sense that we should 'reach' somewhere by moving forwards.

The oscillation that emerged opened up two distinct ways of being with or in the work. As we pressed forwards we just had time to note, sometimes audibly, the immediate things around and about us. We realized very quickly that drawing attention to, through noting or commenting upon people we were passing, was ethically inappropriate. If and when we stopped, it was because the performer 


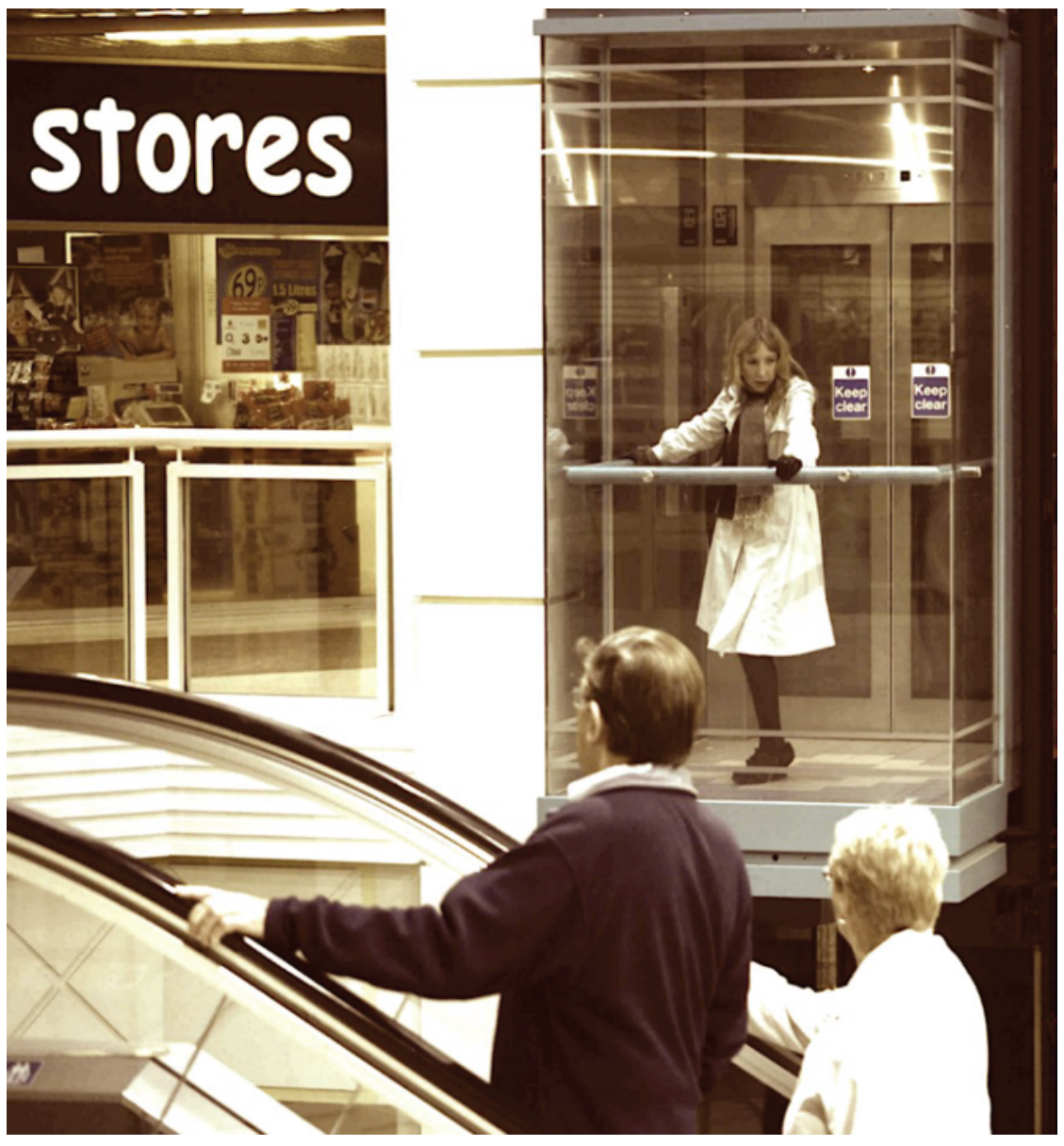

Figure 2: Dream-Work, Nottingham, 2009. Photographer: Tony Judge. (See video three, Nottingham shopping centre) 
pauses allowed space-times for

us as maker-

spectators and

performers to be

invited to dwell

in the 'fourfold'

(Heidegger

$[1951] 1978$

352) and to

drop into our

own slower

rhythms, as the

world around us

continued to race

by stopped, and there was time for us (as makers, then spectators) to look more carefully. It was in these gaps in the walking, exemplified overleaf from Dream-Work in Singapore, where and when dwelling spaces opened up for us to take more time. Indeed, these pauses allowed space-times for us as makerspectators and performers to be invited to dwell in the 'fourfold' (Heidegger [1951] 1978: 352) and to drop into our own slower rhythms, as the world around us continued to race by. As the walks ensued I became less and less interested in the walking parts of the walks and more and more interested in these dwelling places, and the space-times dwelling seemed to invite and open up. Once again the practice was leading the concerns, and helped formulate and cement the questions and enquiries.

\section{Journal notes}

I stop as you move.

Less frequently I move as you stop.

Certainly two directions at the same time.

And now we both stop.

The one and the other, amongst those other others - still-moving.

Your quietening - in relation to my quietening.

Face to face in the event-hood of it all, through this moving fourth wall.

The one is encountering the other, as if again for the first time.

We are held here together, as part of this particular and peculiar etiquette of

performance - this consensuality.

As the walks developed, they became more and more bespoke to each place, in no small part due to the increasing integration of local voices and stories into the soundtrack. Yet even this was as a result of our growing willingness and propensity as makers to dwell, to spend unhurried time, alongside the people and within the places we worked in, to 'value and care for those beings and things within our', now shared 'domain' (Heidegger [1951] 1978: 347). Alongside this, through the walks in Wirksworth, Skegness and Cardiff (2010-14), I had become increasingly engaged in employing dwelling to focus performers and audiences' attention upon still-ing. Indeed, the slower way of being that continued to emerge throughout the process of making spoke directly to my desire to explore how the employment of still-ing might open up a dynamic space-time, where-when it was possible to invite an audience's attention to dwell in their own experience.

\section{Opening up a space-time for still-ing}

We, as makers, participants and/or spectators of studio-based practices and public live performances, are held, however momentarily, in a world that may be a part of, but remains separate from most 


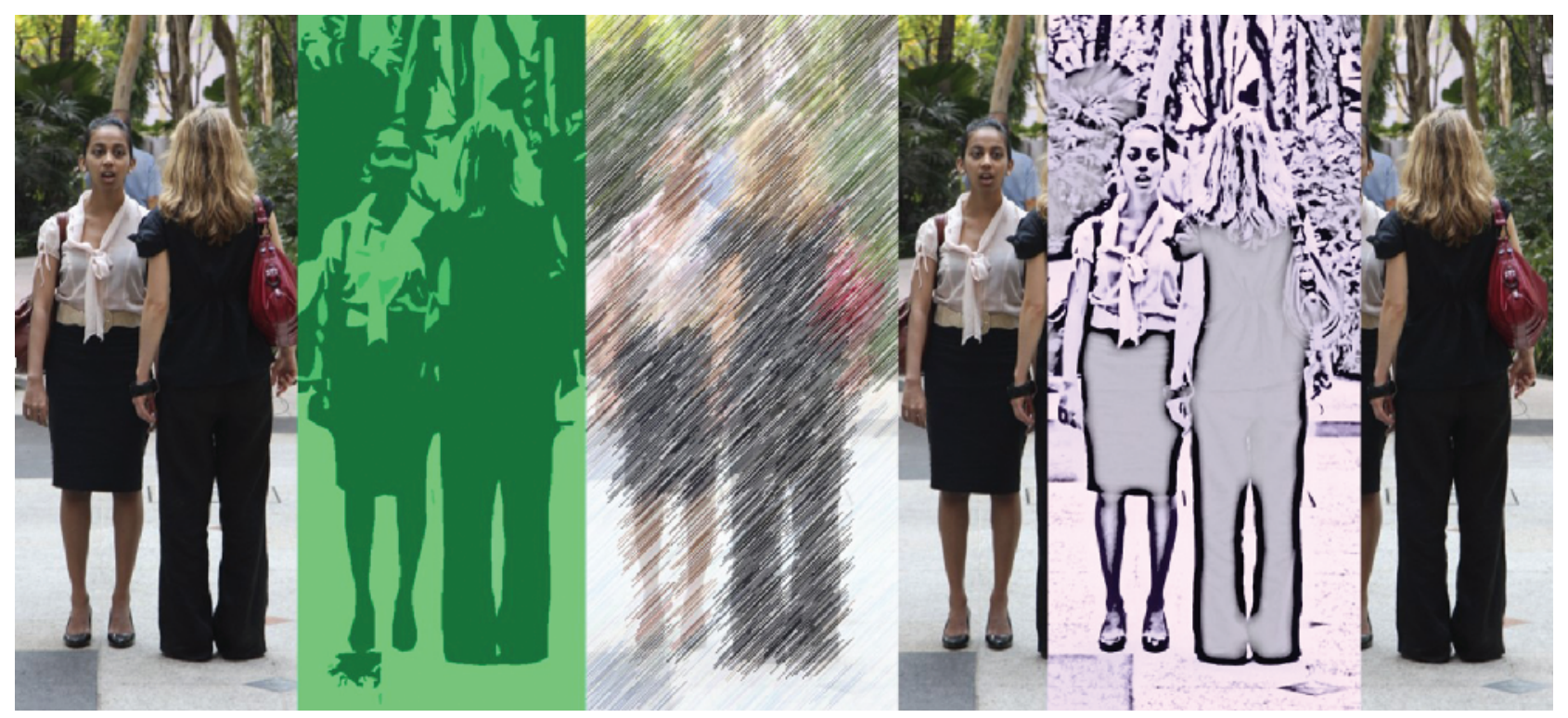

Figure 3: Dream-Work, Singapore, 2009. Photographer: Yuen Chee Wai. (See video four, Singapore soundscape). 


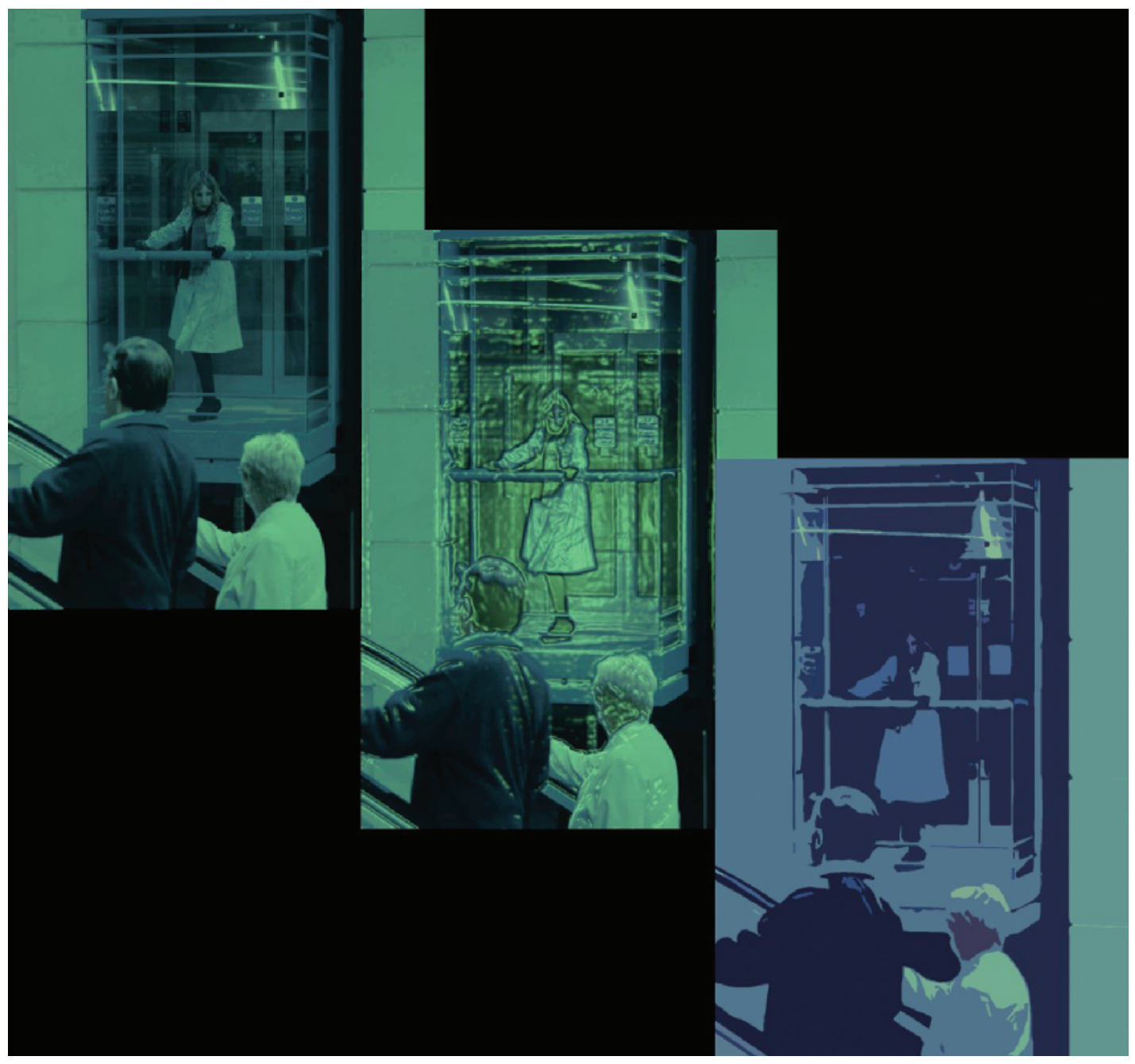

Figure 4: Performer Polly Frame steps aside from the flow of commuters and early morning shoppers in Dream-Work, Nottingham, 2009. Photographer: Tony Judge. (See video five, Nottingham interruptiions). 
people's general everyday experience. We are held (t)here together in these particular and peculiar etiquettes, ${ }^{2}$ as part of the event-hood, the very face to face-ness, of a live, not digitized or prerecorded encounter. This does not predicate that we share the identical time-space leading to an identical experience or memory of that experience, which somehow automatically makes it more real, truthful or authentic than a non-live or any other kind of event.

However, we are held-(t)here in such live event-hoods suspended, alone and together. This suspension in itself another kind of still-ing, made more uncertain in ambulant works like the Dream-Walks, as to exactly what or who will be placed in, or find themselves part, of the frame (see video six, Skegness layering). Such works offer a very specific double choice, the choice to step into the work in the first place, to take the time-space to notice, to attend to the detail and the choice to then stay with what (and who) is presented, or presents themselves, in all its and their glorious minutiae. Practitioner-researcher Katja Hilevaara argues that by employing a combination of 'visual, aural, textual [and] illusory' and a host 'of perceptible sensory stimuli' [...]'theatre performance cuts into the fabric of time an opening, through which time stops momentarily and then starts again' (2012: 71). If, as she argues, such 'temporal interference strategies' are already 'at theatre-makers' disposal' (Hilevaara 2012: 71), then perhaps creating dwelling space-times and employing still-ing within these adds a further possibility to interrupt, even disrupt, our flow of time itself within this already complex situation, bringing attention to the world both outwith and inside ourselves? Following this line of thought, I would assert that still-ing in dance-performance, like John Cage's use of apparent 'silence' in music in 4' 33" (1952), draws our attention to time itself. Cage writes, 'of the four characteristics of the material of music, duration, that is time length, is the most fundamental. Silence cannot be heard in terms of pitch or harmony: it is heard in terms of time length' (1970: 81).

Performers and performance-makers have long since knowingly employed stillness and still-ing to disrupt our sense of time and bring attention to ourselves as audience-spectators. The Spanish performance artist La Ribot identifies this in her suggestion that the 'quietness' in her work is an opportunity for spectators to feel their own 'corporeal presence' (2008) and that through this stillness a space-time is created for contemplation. As Prof Vida Midgelow argues, when talking of the German choreographer Raimund Hoghes' work, stillness forces us as spectators to slow down and 'read ourselves' (2007: 124) into the work, where-when our-selves, alongside the possibility of action or movement, can fill the stillness. I should perhaps reiterate again here that the use of the word still-ing was carefully chosen to suggest the possibility, indeed probability of movement, a spacetime for contemplation upon what had been and the potentiality of what was to become.

Increasingly through the Dream-Walks, I sought to create shared dwelling space-times where, as audiences saw performers bodies still-ing, they might become still-er themselves, and through this still-ing reference their own body-mind in its manifold stillness, enabling still-ing to open up a dynamic space-time (see video seven, Singapore dwelling places). we are held-

(t)here in such

live event-hoods

suspended, alone

and together. This

suspension in

itself another kind

of still-ing

I sought to create

shared dwelling

space-times where,

as audiences saw

performers bodies

still-ing, they

might become

still-er themselves 


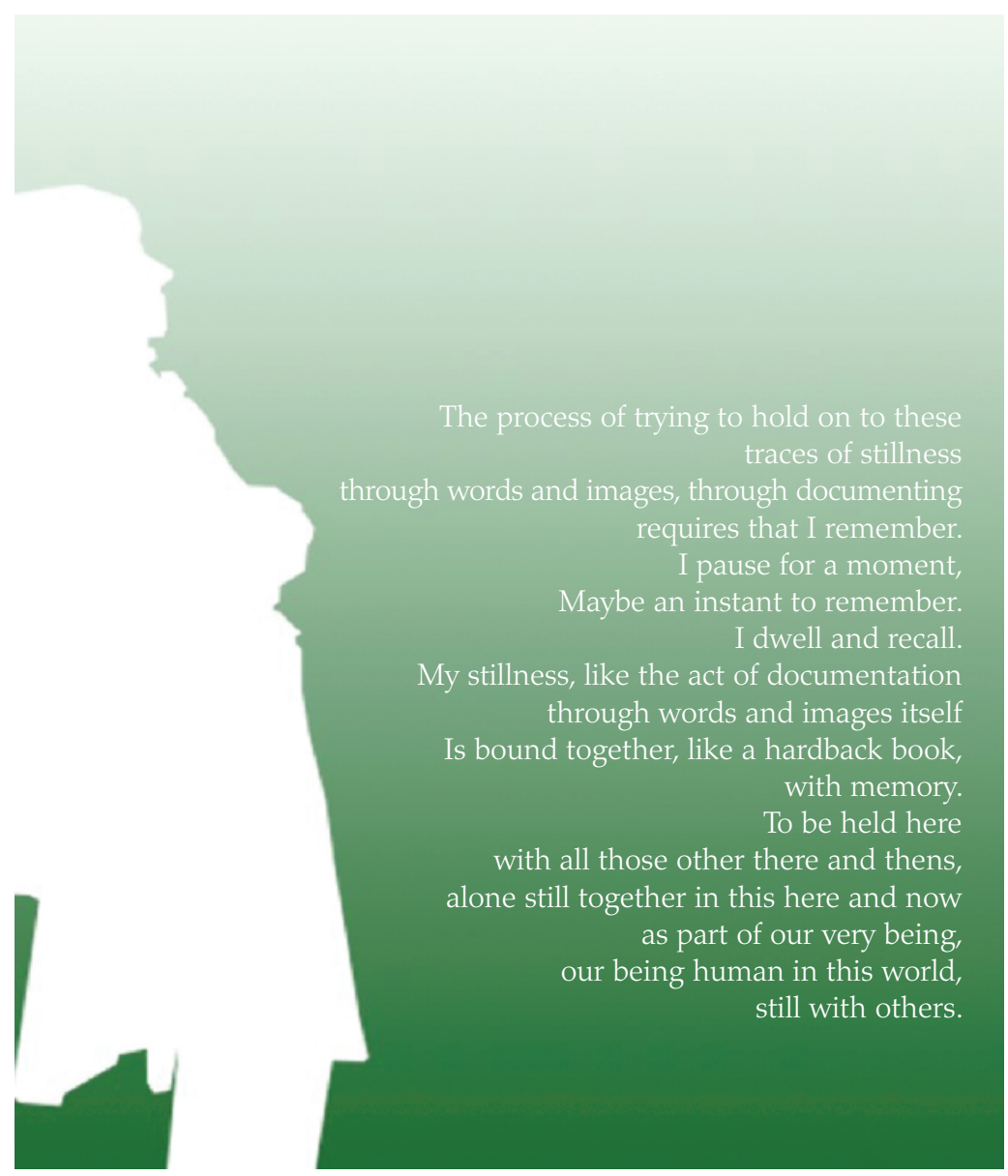




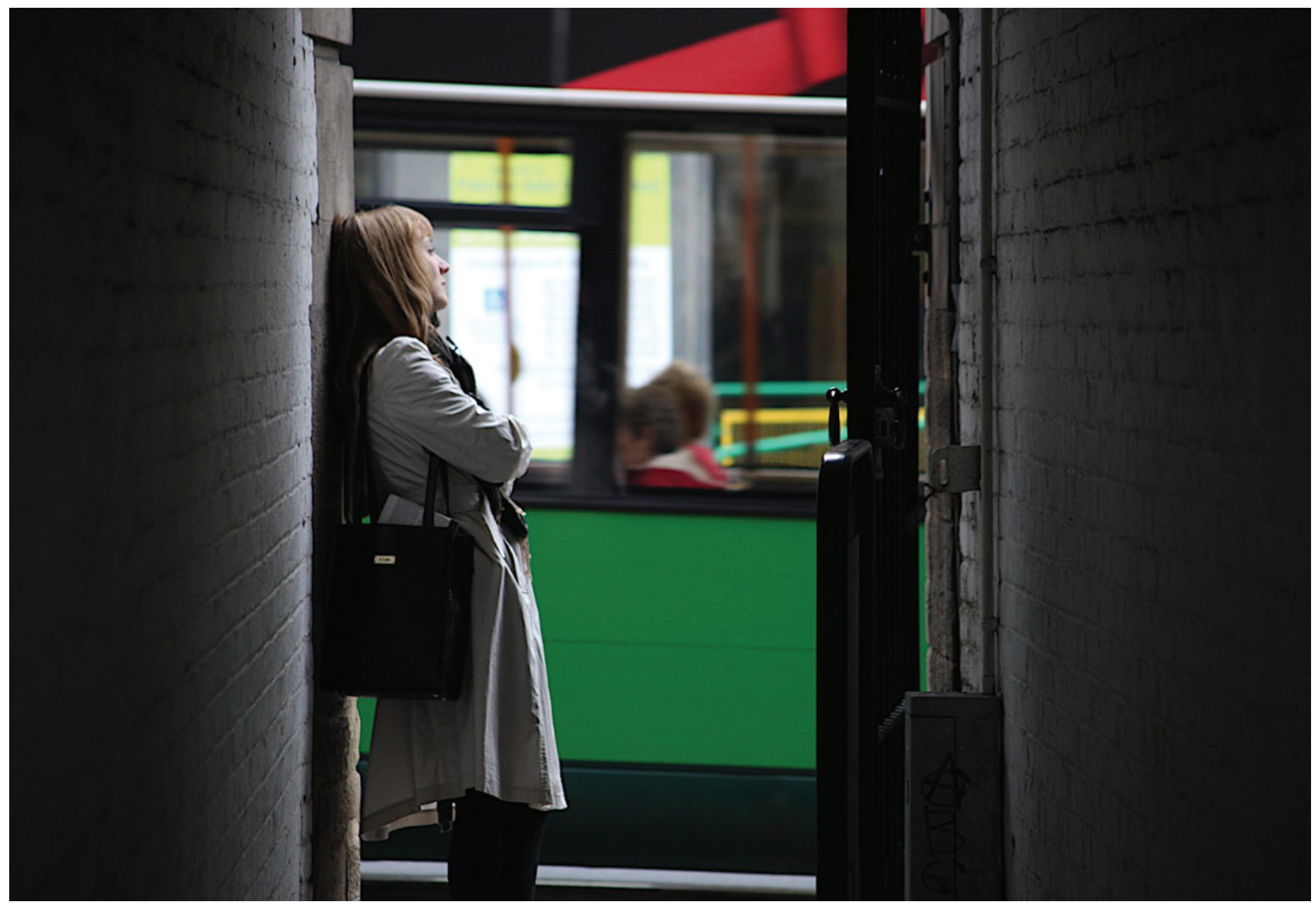

Figure 5: Polly Frame still-ing to watch the traffic flow past in Dream-Work, Nottingham, 2009. Photographer: Tony Judge. (See video eight, Nottingham still-ing). 


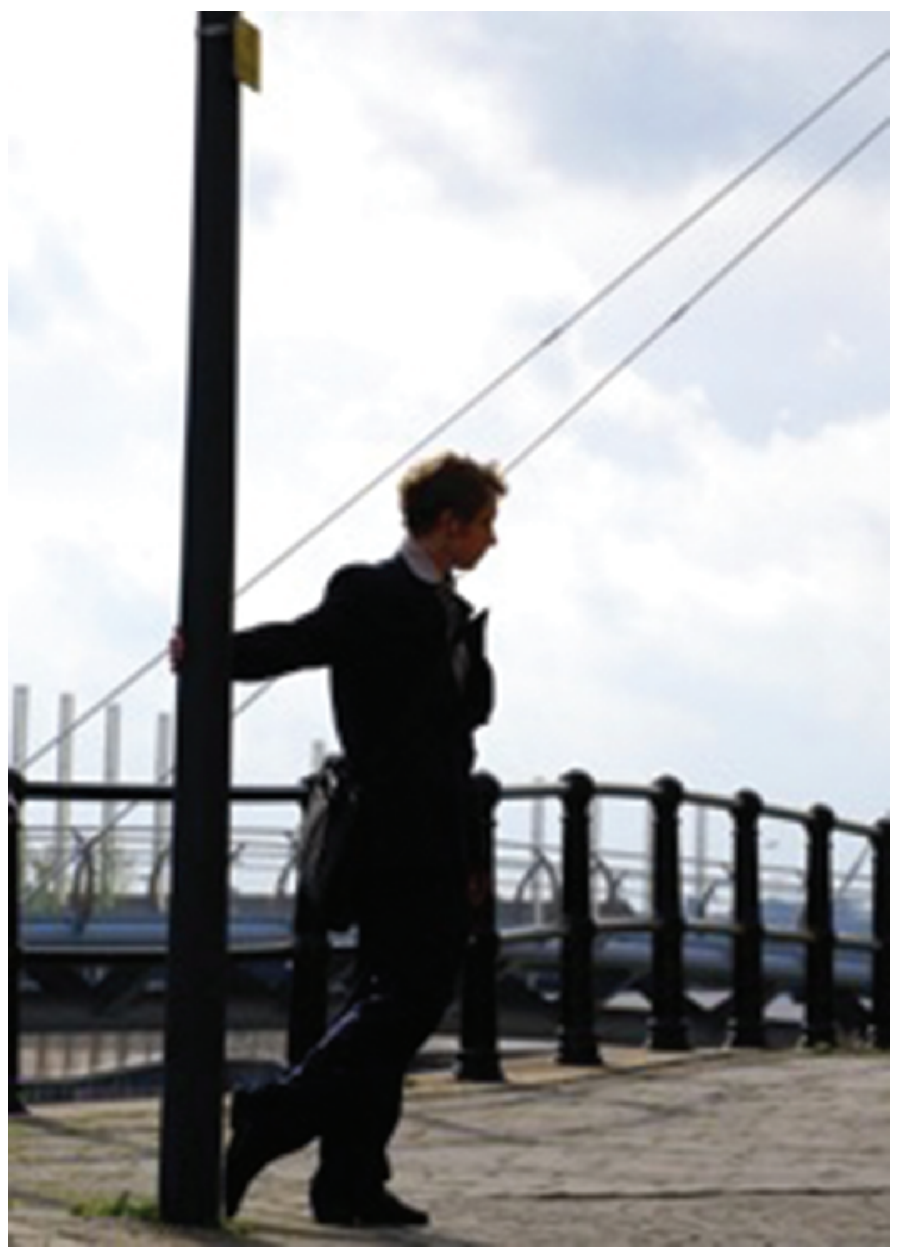

Figure 6: Tom Wainwright at the waters edge, in the fourfold, stepping aside from the morning commute to the station Dream-Work, Bristol, 2010. Photographer: Tina Remiz (See video nine, Bristol contemplations). 


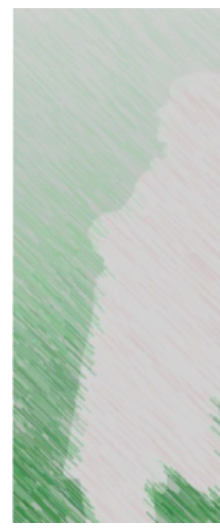

I would never know just how each spectator experienced each still-ing presented in front of them or how such experiences manifested in each of their body-minds. However, as I watched each performance, and dwelt with them in those dwelling places, I began to sense and see for myself how many of these audience-spectators and some of the passers-by were, in fact, moving in and out of a still-ing, their own still-ing. Through this, our mutual still-ing, a space-time had been opened up where-when we (makers, performers and spectators) could slow down. Besides witnessing their physical still-ing, what else might this stilling invite the spectator to do?

As the walks developed, the delicate relationship between creating dwelling space-times for still-ing and the triggering of memories and possibilities for the future became more and more prevalent both within and outwith of the prerecorded sound-scape. In the Wirksworth (2011), Skegness (2012 and 2013) and Cardiff (2014) versions we invited memories of specific eras and events, the opening of the high-peak trail in 1974, recollections of seaside family holidays, the beginning of the Miners' strike in 1984, and in the second Bristol version (2016), children, from Luckwell Primary School, shared their hopes for the future, as audiences paused to gaze down upon the city-scape below (see video ten, dwelling and dialoguing).

Reflecting on Nottingham-based performance collective Open City's work, fine artist Emma Cocker writes that stillness invites both 'the simultaneous possibility of termination' and the promise'of a new beginning' (2013: 96). She affirms that through the employment of stillness it becomes possible to move from a 'paradigm of resistance' [...] 'towards a paradoxically affirming species of refusal or dissidence' that allows or opens up and perhaps 'even attempts to bring into being, another futurepossible way of life' (Cocker 2013: 96). Still-ing viewed from this perspective is not only full of activity itself but invites possibilities, and even incites action. Cocker writes that:

Stillness is always more than it seems, a habit of camouflage that refuses to give much away. Yet under scrutiny stillness becomes a site of perpetual and shifting transformation [...] Stillness thus becomes a foil for infinite and limitless action.

(Cocker 2013: 100, text from Open City Card No.7, produced as part of Open City's contribution for the Dislocate festival)

Cocker's writing helped me to touch upon the complexity of stillness, and offered a further connection to the potential of still-ing. As Zaborowski's neither - nor - ness and Heidegger's both and-ness had helped in framing the delicacy of dwelling, the two closely related in their desire to foreground the present moment with(in) the knowledge that this present already contains the 


\section{Dwelling in these spaces created an opportunity to look beyond the immediate, where-when, witnessing others still-ing, we could 'drop into' our own slower rhythms.}

memory and promise of change. In both, I could not help but hear pre-echoes and echoes of T. S. Eliot's still point,'neither arrest nor movement' ([1944] 1974: 191), not quite either, although both the promise and reminder of both.

The Dream-Walks created space-times for more prolonged contemplation by clearing spacetimes for reflection. Dwelling in these spaces created an opportunity to look beyond the immediate, where-when, witnessing others still-ing, we could 'drop into' our own slower rhythms. Through this clearing, through dwelling, which invited attention to, including the naming within the soundscape of, a host of 'visual, aural, textual [...] sensory stimuli' (see video eleven, dwelling and the senses), we had cut 'into the fabric of time an opening, through which time stops momentarily and then starts again' (Hilevaara 2012: 71). I wondered how the employment of still-ing might support makers who are concerned with audiences and their relationship to meaning-making?

\section{Emancipated spectators}

Throughout all the Dream-Walks, the spectators could choose either to dwell with us and attend to the still-ing and to step into the openings created by them, or not. However, there was still an interpretative task to be undertaken or ignored by the spectators. The employment of stilling is a compositional strategy; it frames and points to others, to places, to things, to self, to the fourfold and this is inextricably linked to meaning-making. If we (as makers) place stillnesses within the openings, that performance 'cuts into the fabric of time' (Hilevaara 2012: 71), does the employment of still-ing inevitably support those theatre makers who are concerned with exploring the possibility of surrendering meaning-making to the spectators? Hilevaara argues that each audience member makes their own interpretations of the work placed before them and that 'there are a multitude of transformations in motion' (2012: 75), and this leads to a democratization in theatre. I would not go this far. The frames are still primarily being set up by the maker-performer, although we do move towards the edges of a more democratic relationship. However, employing still-ing certainly seems to support this notion of opening up a space-time that invites; that is, gives permission and multiple opportunities for meaningmaking.

In his essay ‘The emancipated spectator' (2007), Jacques Rancière reflects upon the separation of actor and spectator, arguing how historically 'being a spectator' has meant'looking at a spectacle' and how looking has been placed in opposition to 'knowing' (2007: 272). Acting, Rancière argues, has been aligned to moving around, being physical and being in control, whilst audiences, mostly, remain seated and passive. This suggests an alignment with 'illusion and passivity' for the spectators in direct contrast to the performers alignment with 'knowledge and action' (2007: 272). 


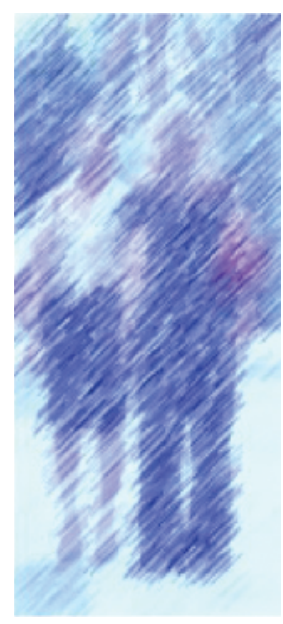

The Dream-Walks and the creation of dwelling places, and the employment of still-ing within them appears to challenge at least some of these apparent givens. In The Dream-Walks it was the performers who were very often still (not moving externally) in the dwelling places, and they used the act of looking at each other or the surroundings, never passers-by, as a central focusing feature. It was the audience who were deliberately invited to move around, to change their point of view, if they wanted. However, this invitation for the audience to move in itself should not be confused with the audience becoming emancipated; they could, of course, move and still be passive receivers (see video twelve, attending through still-ing).

Rancière acknowledges that there is much theatrical history and practice that has challenged such a dualistic position, but that this can still be broadly divided into two opposing ways of looking at this same passive spectator active performer question. Rancière suggests that the emphasis has been placed upon the audience, on the one hand under the Brechtian influenced strategy of becoming more distant, or on the other, firmly in the Artaudian territory, of being engulfed by the action, with the intention of reducing the distance between performers and audiences. As a choreographer, I found Rancière's description of how the 'project of reforming the theatre' had'ceaselessly wavered between [...] two poles of distant inquiry and vital embodiment' charmingly provocative and his call for a theatre where spectators could 'become active participants in a collective performance' (2007: 272) emboldening.

However, in both of the approaches described above, although they may support an apparently 'better' way of looking, the spectators' position as a viewer still remains, and so, argues Rancière, does the same active actor-doer, and passive audience-watcher problem. Theatre, Rancière argues, is still'resting on some key equivalencies' such as the 'equivalence of theatre and community, of seeing and passivity' and a series of binary'oppositions between collective and individual, image and living reality, activity and passivity, self-possession and alienation' (2007: 274). Like many makers, I was interested in how my practice might wrestle and perhaps even begin to challenge some of these apparent'equivalencies'.

Increasingly, the Dream-Walks were deliberately set up to explore and challenge some of these underlying assumptions. The spectators still viewed but perhaps some of their viewpoints (and roles) were altered, and the roles and 'actions' and non-actions of the performers, even who the performers were, as passers-by inadvertently became part of the wider scene, were consistently called into question. 


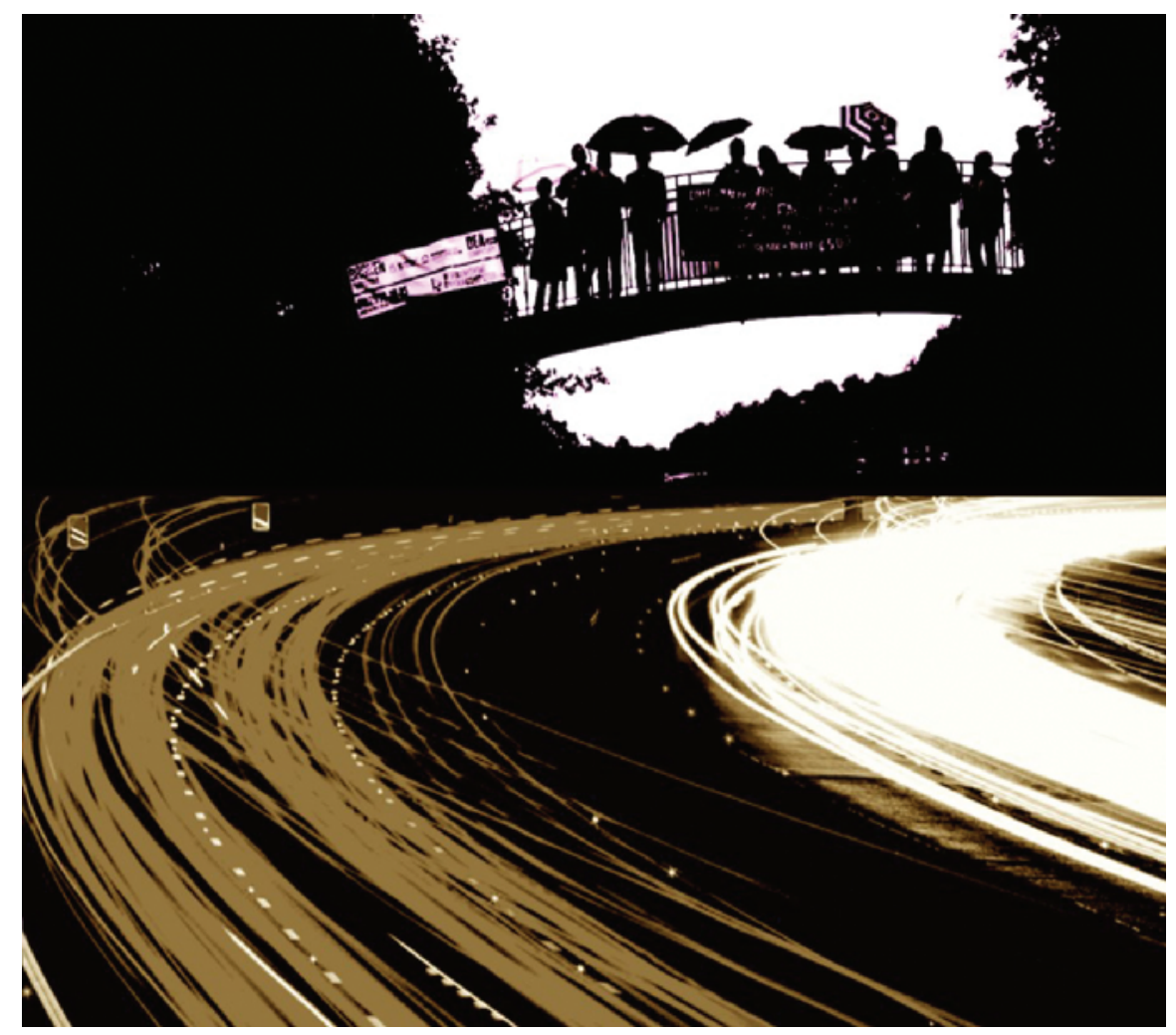

Figure 7: Dream-Walk, Wirksworth, 2011. Photographer: Tony Judge. Performers and audiences dwelling together on the central bridge overlooking the town's main road. (See video thirteen, Wirksworth geology). 
Whilst the employment of still-ing, of apparent non-action, may not have propelled an audience into obvious political action, it did draw the attention, for those who choose to take the time to notice, to the 'heterogeneous temporal durations operating beneath and within' and around 'the surface appearance of the dominant structure's homogeneous flow' (Cocker 2013: 94). In and through this deliberate mixing of frames, against the flow of the commute or the well-worn, holidaymakers walk from the station to the beach in Skegness for example, and through the placing of the performers in the everyday, the watchers and passersby became part of the action; they were often in the midst of the work and in their collective watching and moving through the space seemed to form their own collective energy (see video fourteen, local environments).

\section{Being alone still together again. Let's dwell a moment longer [...] \\ I may or may not be able to dance those steps you have just danced, but I can be still, still alongside.}

The dwelling places created, heightened by the still-ings within them, opened up space-times to look and to see differently, and from different places and view-points. They invited audiences and performers to take time and make space. Indeed, the Dream-Walks led towards a kind of emancipation through the creation of more dynamic space-times for the spectators where-when the process of verification' heralds or suggests an 'equality of intelligence' (Rancière 2007: 275) and experience. Rancière's idea of moving towards an 'equality of intelligence' is important as it cuts to the core of what dwelling and still-ing can offer, bringing a necessary delicacy of thinking to the issue: ' $[\mathrm{t}]$ he equality of intelligence is not the equality of all manifestations of intelligence. It is the equality of intelligence in all its manifestations' (Rancière 2007: 275). This commitment to an 'equality of intelligence' is crucial, and helps guard makers against the tendency in some artistic and cultural circles to be patronizing towards our audiences.

Whilst continuing to draw upon the much earlier Jacotot, ${ }^{3}$ Rancière explains that it is through explication that the 'master' always knows the precise distance between 'ignorance and knowledge' and that this is something that in a hierarchical pedagogical structure is impossible for the 'ignorant [...] to know' (Rancière 2007: 275). He elucidates how a standard pedagogical relationship is built upon the teacher being at least one step ahead, that is, they always know more about that particular thing or subject than their pupil. Jacotot's thinking on the other hand proposes attending to a 'progressive method' (Rancière 2007: 275), which is methodical and moves from the 'simplest to the most complex' ${ }^{4}$ (Rancière 2007: 276). This method recognizes and values that the student may have learnt other things, maybe even many things through other means, by looking

\section{Dream-Walks led}

towards a kind

of emancipation

through the

creation of more

dynamic spacetimes for the

spectators 


\section{permission}

to dwell in

possibilities and

imaginings and

that in turn

invited them to

place or reference

them-selves,

their knowings

and their non-

knowings within

such frames, alone

still together and listening and then repeating what they have'seen and heard' (Rancière 2007: 275). This can be 'a process of groping by hit-and-miss' (Rancière 2007: 275). But this, Jacotot argues, is how we all have learned; it is universal and, interestingly for a choreographer and a pedagogue, it is not necessarily word-based.

This thinking was useful to me as I was concerned with opening up a space-time through dwelling for the spectators to observe and feel, both what was external and internal, from a position of their own knowledge of their own experience of stillness and still-ing towards the unconcealing of other, at present, non-knowings. I knew that I could not make others see and experience still-ng in the same ways that I did, and after all why would I want to? However, I could invite the opening up of a space-time, through the universal and yet very subjective experience of still-ing and through such an opening welcome each spectator's own meaning-making.

It is this idea that lay at the heart of my desire to create dwelling places for performers and audiences through the employment of still-ing. Jacotot wanted a pedagogical model that opened up an equality between translation and counter-translation. Where-when the pupil 'can learn, sign after sign, the resemblance of what he ignores with what he knows' (Rancière 2007: 275). He learns as he has learned; he is making comparisons between those things he knows and those things he does not yet know but may want to learn about. I wanted to create space-times for spectators to be present in their own 'presencings' (another useful term borrowed from Heidegger ([1956] 1978: 151)), to choose to be aware of what is/was inside and alongside them, to notice the extraordinary ordinariness and to be active in their own experiencing and meaning-making. Rancière's concluding remarks reflect upon the apparent collective power in theatre that, he suggests, is actually only the power of each audience member 'to translate in their own way what they are looking at' (Rancière 2007: 278). Throughout the making and siting of the Dream-Walks I became increasingly concerned with employing still-ing to create space-times that gave audiences permission to dwell in possibilities and imaginings and that in turn invited them to place or reference them-selves, their knowings and their non-knowings within such frames, alone still together.

The 'equality of intelligencies' that can bring people together in performance contexts is ironically related to individual (and in some ways independent) meaning-making. It is concerned with spectators taking part in their own stories, that which Rancière would describe as 'associating and dissociating' (Rancière 2007: 279). Emancipation is the blurring of 'the opposition between those who look and those who act, between those who are individuals and those who are members of a collective body' (Rancière 2007: 279). Ultimately, The Dream-Walks were concerned with challenging and blurring boundaries, in both their contexts and content. Rancière concludes that theatre should 'call for spectators who are active interpreters' (Rancière 2007: 280). Creating dwelling places for stilling could not help but demand this too. 


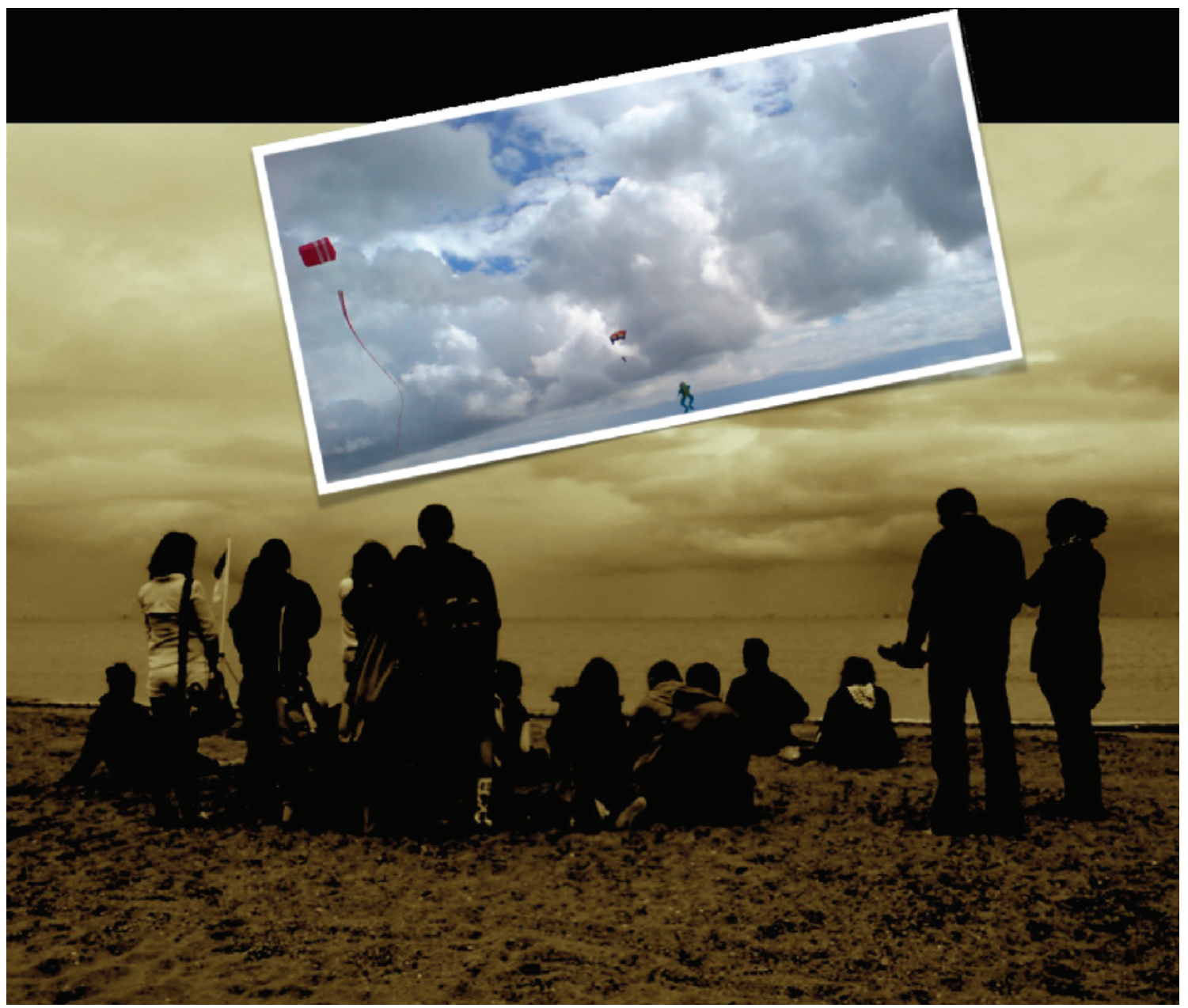

Figure 8: Dream-Walk, Skegness, 2013. Photographer: Tony Judge. The audience gathered together behind performer Graeme Rose, gazing out to the sea and wind-turbines beyond. (See video fifteen, dwelling in the 'fourfold'). 
Such a sensibility, this new-found propensity towards dwelling and the space-times that still-ing can invite for makers, performers and audiences, will never leave me. There is no going back. Dwelling supports and invites still-ing. The practice, and my discoveries as a result of the whole research process, has propelled me into the development and siting of a new work, which characteristically began from where the Dream-Walks left off. Still Moving: Moving Still, a site-specific performance installation, employs a growing palette of still-ings in public buildings for audience-participants and performers. Still Moving: Moving Still is concerned specifically with how this palette of still-ings and their function and potential as choreographic strategies may relate to audience and public engagement. The work has most recently been commissioned for Birmingham's International Dance Festival, emerging out of a conference focused on Slowing and Stilling, held at Birmingham Conservatoire, supported by DanceXchange and Birmingham City University (2018) and is in an early research and development phase, prior to a performance as part of Nottingham's New Art Exchange's plans for International Women's Day 2021.

Dwelling-as-practice has become a central strand in our newly formed Dance and Somatic Practices Research Group (DSRG ${ }^{5}$ ) at the University of Central Lancashire (UCLan), and has been employed as both subject and methodology within both our teaching and research. As a consequence of such a focus, course timetables have been altered to allow more space for staff and students to slow down and focus more on studio practice, and related pedagogically based dissemination has supported staff from a wide range of disciplines across UCLan and beyond to employ dwelling in both academic and pastoral contexts. As a practitioner-researcher, I now have the courage through this research to resist the propensity to perpetuate the myth that we must always move forward to keep ahead, sometimes stepping aside, dwelling with and outwith, uncovers a richness and depth for makers, performers and audiences that cannot be underestimated or predicted. Let me stay with the 'fourfold' and let my practice continue to lead the way (see video sixteen, the extra-ordinary ordinary).

\section{References}

Bachelard, G. ([1958] 1994), The Poetics of Space (trans. M. Jolas), Boston: Beacon Press.

Bodies in Flight (2009), Dream-Work, live performance, performed by Polly Frame and Sam Halmarack, Singapore, 24-29 June.

(2009), Dream-Walk, live performance, performed by Polly Frame and Sam Halmarack, Nottingham, 20-22 October.

_ (2010), Dream-Walk, live performance, performed by Sam Halmarack and Tom Wainwright, Bristol, 9-10 May. 
(2011), Dream-Walk, live performance, performed by Neil Johnson and Graeme Rose, Wirksworth, 18 September.

(2012), Dream-Walk, live performance, performed by Neil Johnson and Graeme Rose, Skegness, 30 June-1 July.

(2014), Dream-Walk, live performance, performed by Tim Atack and Polly Frame, Cardiff, 2 July.

_ (2016), Dream-Walk, audio work, performed by Tom Wainwright and composed by Neil Johnson, Bristol, 17 October.

Burt, R. (2005), 'Another Dream, Raimund Hoghe at the ICA', London Mime Festival, Critical Dance, 2 February, http://www.balletdance.com/forum/viewtopic.php?p=38174\&sid=051254b046034b7c 4a6bdab21c5c2fed. Accessed 21 May 2014.

Cage, J. (1952), 4' 33", live performance, performed by David Tudor, Maverick Concert Hall, Woodstock, NY. 29 August.

- (1961), Silence: Lectures and Writings, Middletown: Wesleyan University Press.

_ (1970), John Cage by Cage (ed. R. Kostelanetz), New York and Washington, DC: Praeger Publishers.

Cocker, E. (2013), 'Performing stillness: Communities in waiting', in D. Bissell and G. Fuller (eds), Stillness in A Mobile World, Oxford: Routledge, pp. 87-106.

Eliot, T. S. ([1944] 1974), The Four Quartets, London: Faber.

Heathfield, A. (2004), Live Art and Performance, London: Routledge.

(2006), 'After the fall dance-theatre and dance-performance', in J. Kelleher and N. Ridout (eds), Contemporary Theatres in Europe: A Critical Companion, London and New York: Routledge, pp. 188-98.

Heidegger, M. ([1927] 1966), Being and Time (trans. J. Stambaugh), Albany: State University of New York Press.

—_([1951] 1978), 'Building dwelling thinking', in D. F. Krell (ed.), Basic Writings, London: Routledge, pp. 343-364.

_[1956] 1978), 'The origin of the work of art', in D. F. Krell (ed.), Basic Writings, London: Routledge, pp. 139-212.

Hilevaara, K. (2012), 'Idle fancies, lucid dreams and startling memories: Remembering as a form of active spectatorship', How Performance Thinks Conference, Co-Hosted by PSi Performance and Philosophy Working Group and the Practice Research Unit, Kingston University, London Studio Centre, 
13-14 April, London: PSi, pp. 70-76, http://performancephilosophy.ning.com/page/how-performance-thinks. Accessed 24 January 2013.

Hoghe, R. (2000), Another Dream, live performance, performed by Raimund Hoghe, Kaaitheater, Brussels, 6-9 December.

- (2005), Swan Lake, 4 Acts, live performance, performed by Ornella Balestra, Brynjar Bandlien, Lorenzo De Brabandere, Raimund Hoghe and Nabil Yahia-Aissa, Grammont Theatre, Montpellier, 4 July.

Lepecki, A. (ed.) (1995), 'Inscribing dance', Of the Presence of the Body: Essays on Dance and Performance Theory, Middletown: Wesleyan University Press, pp. 124-39.

(1999), 'Stillness and the microscopy of perception', 5th International Performance Studies Conference, Aberystwyth, Wales, 9-12 April.

— (2006), Exhausting Dance: Performance and the Politics of Movement, London and New York: Routledge.

Lerman, L. and Borstel, J. (2003), Liz Lerman's Critical Response Process: A Method for Getting Useful Feedback on Anything You Make, From Dance to Dessert, Washington: Dance Exchange.

Midgelow, V. (2007), Reworking The Ballet: Counter Narratives And Alternative Bodies, London and New York: Routledge.

Rancière, J. (2007), 'The emancipated spectator', Artforum, XLVI:7, pp. 270-81.

Ribot, M. La (1998), Mas Distinguidas, live performance, performed by Maria La Ribot, Sandfield Centre, Nottingham, 9-10 May.

— (2000), Another Bloody Mary: Still Distinguished, live performance, performed by Maria La Ribot, Arsenic Theatre, Lausanne, 15-17 September.

- (2008), Panoramix: Live Art Development Agency Catalogue (trans. L. Kerslake), London: LADA, http://www.thisisiveartco.uk/projects/live_culture/laribot.html. Accessed 3 January 2012.

Sapir, M. (2006), 'Exhausting Dance', book review, Dance Theatre Journal, 22:1, pp. 49-50.

Stuart, Meg (2008), 'Nothing is forever' (interview with Gia Kourlas), Time Out, New York, 24 January, http://www.timeout.com/newyork/dance/nothing-is-forever. Accessed 26 April 2014.

Zaborowski, H. (2005), 'Towards a phenomenology of dwelling', Communio: International Catholic Review, 32, Fall, pp. 492-516. 


\section{Suggested citation}

Giddens, Sara, Judge, Tony and Law, John (2019), 'Dwelling in-between', Choreographic Practices, 10:2, pp. 213-37, doi: https://doi.org/10.1386/chor_00004_1

\section{Contributor details}

Dr Sara Giddens is a choreographer and creative facilitator. She teaches on the Dance Performance and Teaching course at the University of Central Lancashire. Having worked on the Articulating Dance' project, as part of Choreographic Lab, Sara completed a practice-based Ph.D. entitled 'Still small acts' in 2015, co-hosted by Dance4 and Middlesex University. She continues to develop, make and tour performance-based work with Prof Simon Jones (Bristol University) through their company Bodies in Flight (1989), who are celebrating 30 years of making performance work with their new show Life Class and stand-alone exhibition Flesh and Text.

Contact: Faculty of Culture and the Creative Industries, UCLan, Preston, PR1 2HE, UK. E-mail: sgiddens@uclan.ac.uk; sara@creativeforum.co.uk

Web address: www.bodiesinflight.co.uk; http://uclandanceandsomaticpracticeresearch.com/

스 https://orcid.org/0000-0003-0680-2189

Tony Judge is a photographer and filmmaker who has exhibited works for gallery, screen and broadcast including Channel 4, BFI, ICA and MOMA NYC. He is founder and director of Creative Forum, a lens-based production company. He is currently developing a documentary series The Fine Art of Rock that profiles a range of artists who have risen to fame with bands such as The Clash, The Specials and The Farm. He has been working with Bodies in Flight since 1989 when he was producing a documentary of Live Art at the Third Eye Centre (Glasgow). His first moving image collaboration with the company was Flesh \& Text in 2000. He works as a creative mentor and teaches filmmaking at Leeds Arts and Edge Hill Universities.

E-mail: tony.judge@leeds-art.ac.uk; tony@creativeforum.co.uk

Web address: www.creativeforum.co.uk

This article marks the beginning of Giddens' collaborative relationship with designer Dr John Law as they seek to develop outputs that foreground the interrelationship between image and text in such contexts. Law is the research and commercial bid writer for the University of Central Lancashire's Faculty of Culture and the Creative Industries. With 30 years' experience in the higher education sector, his main interests lie in design and innovation, collaborative partnerships, research 
cooperation and internationalization. A former Head of Design at both Birmingham City University and the Hong Kong Design Institute, he continues to support a range of education activities in the Performing Arts.

E-mail: jlaw3@uclan.ac.uk

Sara Giddens, Tony Judge and John Law have asserted their right under the Copyright, Designs and Patents Act, 1988, to be identified as the authors of this work in the format that was submitted to Intellect Ltd.

\section{Notes}

1. I would substitute a knowing here as it suggests a more holistic, multi-modal approach to how we might come to know a thing or person.

2. I am constantly amazed how generous participants and audience-spectators are in abiding by the rules of workshops and performances.

3. Rancière's essay is a'meditation' (Rancière 2007: 272) on Joseph Jacotot's work. Jacotot was a French professor who ruffled feathers in the academic world in the early nineteenth-century through his suggestion that'an ignorant could teach another ignorant what he did not know himself' (Rancière 2007: 272).

4. Rancière writes that 'theatre is a self-suppressing mediation' (2007: 274). This is familiar to us because it is the same process at the heart of standard pedagogical relationships that posit the reduction of the gap between knowledge and ignorance as the key aim. Ironically to reduce this gap the teacher has to perpetuate it to remain one step ahead. This is based on 'inequality', which Jacotot refers to as a'process of stultification' (Rancière 2007: 275), that is, to render useless.

5. http://uclandanceandsomaticpracticeresearch.com/. 


\section{Scene}

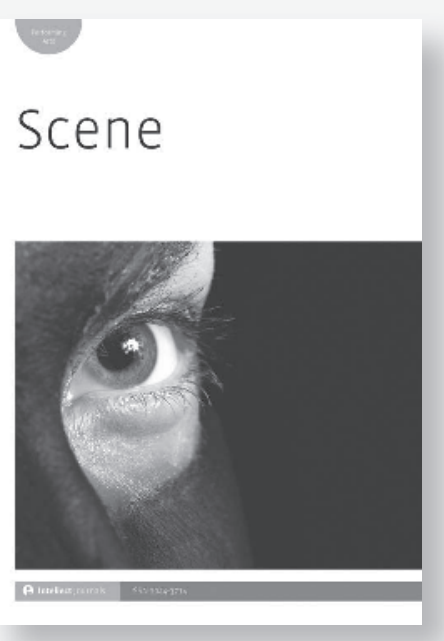

ISSN 2044-3714 | Online ISSN 2044-3722

2 issues per volume | First published 2013

\section{Aims and Scope}

Scene is dedicated to a critical examination of space and scenic production. Central to this journal is the understanding that the designer's contribution to a production involves much more than providing a visual background. Scene welcomes new critical frameworks for the scholarship of creating a scene and invites contributions which explore all aspects of design contexts for live and recorded performance - particularly those which pay attention to the shaping of artistic vision, aesthetic sophistication, critical thinking and craft.

\section{Call for Papers}

Articles, interviews, visual essays, reports from conferences and festivals are welcome from scholars and practitioners. Contributors are encouraged to approach design for entertainment from any discipline and to turn their attention to practices from all countries and in all languages.

\section{Editors}

Christine White

De Montfort University, UK

christine.white@dmu.ac.uk
Alison Oddey

Nottingham Trent

University, UK

alison.oddey@ntu.ac.uk

To order this journal online visit our website: www.intellectbooks.com

f @IntellectBooks | olntellectBooks | 의 intellectbooks | in Intellect Books

